УДК 811.111'276.6:327

DOI https://doi.org/10.32838/2710-4656/2021.5-1/31

Sydorenko S. I.

National Aviation University

\title{
DIPLOMATIC LANGUAGE AS A REFLECTION OF A POLITICAL STANCE REGARDING THE CONFLICT IN EASTERN UKRAINE
}

The paper features the results of a content analysis of the speeches delivered at the 8726th meeting of UN Security Council on the situation in eastern Ukraine held on 18 February 2020, with the specific goal to explore the correlation between certain speech markers and the political stand of the speaker, in this particular case - each member country's stance on the agenda and the extent they choose to show their position between the two parties of the conflict, Russia and Ukraine. As a genre of diplomatic discourse, speeches delivered at the UN Security Council meetings are expected to be carefully balanced in terms of the language and restrained in terms of emotions. Thus, any cases of deliberate emotionality, explicit evaluation of other participants' actions and deviation from diplomatic impartiality and ambiguity are meant to signal the speaker's distinctive position on the agenda. The analysis resulted in singling out language markers that break with the traditional matter-of-fact tone of diplomats'speeches on such occasions, the major of them being the use of emotive vocabulary, emphatic syntax, metaphors, hyperboles, idioms, evaluative language, labelling, accusatory rhetoric, modal verbs denoting obligation and determination. The hypothesis that the more frequent is the use of these markers in a speech, the more clearly the speaker wants to show the position of his/her country regarding the parties of the Russian-Ukrainian conflict, has been fully confirmed. In our analysis, we also looked at two auxiliary markers, the number of mentions of proper names identifying the parties to the conflict and the length of speeches. The first of them showed that the participants'desire to "annoy" Russia is directly proportional to the number of Russia's mentions in their speeches. The length of speeches also in most cases turned out to be indicative of the speaker's intention to clearly show their position between the conflicting parties. Characteristically, China's representative's speech appeared to be not only devoid of any counter-matter-of-fact markers, i.e. the most generally and neutrally phrased, but also the briefest.

Key words: diplomatic language, diplomatic speech, counter-matter-of-fact markers, emotional language, evaluative language, political stance, conflict in Eastern Ukraine.

Statement of the problem. Encyclopedia Britannica defines diplomacy as "the established method of influencing the decisions and behaviour of foreign governments and peoples through dialogue, negotiation, and other measures short of war or violence" [13]. Being an alternative to warfare, diplomacy relies above all on language as a means of resolving conflicts and reaching agreements. In today's world, torn by numerous military conflicts and increasingly exposed to danger by the muscle-flexing of superpowers, the ability of nations to find compromise through diplomacy is the matter of nothing short of survival. In terms of linguistics, the awareness of the crucial peace-keeping role of diplomacy brings about a growing attention to the diplomatic discourse and its linguistic characteristics.

Over the recent years, the conflict in eastern Ukraine has been continuously demanding attention of the world's top diplomats. Since 2015, when the UN Security Council adopted resolution 2202 on the package of measures for the implementation of the Minsk agreements, the situation in eastern Ukraine has been the agenda of a series of the Council meetings. Though generally criticized as ineffective, these exchanges of opinions on the highest diplomatic level nevertheless remain vital for Ukraine in its struggle against Russia's aggression. The speeches delivered by the participants of these meetings are a specific genre of diplomatic discourse whose major aim is to voice the official stance of each member state on the problem discussed. As the diplomatic discourse is known to be characterized by carefully balanced wording and well-checked, often intentionally ambiguous, mode of expression, it is of particular interest for a linguist to see how the intended message is wrapped in the language form and how the chosen form, remaining in conformity to the standards of the diplomatic language, can reveal the standing of the member country as regards the conflict.

The analysis of recent research and publications. Diplomatic discourse has been recently increasingly attracting linguists' attention, obviously due to 
the role of diplomacy in the contemporary world. The researchers have above all been looking for distinctive characteristics of diplomatic discourse which make it possible, on the one hand, to discriminate it from the general political discourse, and on the other hand, to differentiate it from closely related types of discourse, such as publicistic and official. Having defined diplomatic discourse as a special type of communication, the researchers further explore its genres, structure of various types of texts, specificity of language use, i.e. its characteristic lexical, grammatical, stylistic and rhetorical features, and pragmatic aspects.

Adrian Beard underlines the essential role of the language in political communication, writing that "language is ... a means of presenting and shaping argument" [10, p. 18]. In his book "The Language of Politics" he examines how politicians describe political stances and explores some of the most common linguistic features of political speeches. His suggestion that "when analysing the language of a political text ... it is important to look at the way the language reflects the ideological position of those who created it" [ibid.] served an additional motivation for this research.

In [15] Nick Stanko argues that "the use of language in diplomacy is of major importance, since language is not a simple tool, vehicle for transmission of thoughts, or instrument of communication, but very often the very essence of the diplomatic vocation" $[15$, p. 39].

A historical and anthropological study of the forms of diplomatic expression was conducted by Olivier Arifon in [9]. Pedagogical issues of teaching language of diplomacy have been featured in [14].

Hafriza Burhanudeen in [11] explores the essence of diplomatic language, claiming that "diplomatic language is expected to consistently contain language that promotes mutual cooperation over conflict and divisiveness even if no specific outcome is ultimately achieved" [11, p. 50].

Morphological characteristics of the diplomatic language have been studied in [18]. M. Beliakov in [1] studied semantic and semiotic aspects of the diplomatic discourse, arguing that in this type of discourse there can be no "accidental" words, and the words are supposed to deliver to the addressee the meanings meant by the speaker [1, p. 61].

V. Skriabina in [7] researched the linguistic aspects of persuasion in diplomatic communication, drawing attention to the fact that if earlier this communication was supposed to be predominantly neutral, with the personal, subjective touch reduced to the minimum, today, under the influence of social and politi- cal changes, the diplomatic discourse is getting more aggressive and expressive [7, p. 267].

A series of studies on English diplomatic discourse have been conducted by N. Kashchyshyn [2; 3; 4]. The researcher differentiates the diplomatic discourse from other types of discourse, defining it as a specific arrangement of language means which coincides with the notion of the totality of texts on diplomatic topics which function in the sphere of diplomacy. She looks at the diplomatic discourse as a reflection of the institution of diplomacy and international communication on the level of language units [2].

Specific features of the diplomatic speech as a variant of the official style have been studied in [5]. The authors draw attention to the fact that diplomatic texts often go contrary to the neutral tone typical of the official style, which is explained by pragmatic factors [5, p. 123].

The common and the specific features of the political and diplomatic discourses have been the object of study in [8].

Among case studies in the field of the diplomatic discourse, we should mention the comprehensive research by Germana D'Acquisto [12], who applies methods from corpus linguistics to investigate diplomatic discourse in UN Resolutions on the Arab-Israeli conflict from 1947 to the present day.

Linguistic features of Russian diplomatic discourse were studied by V. Yapparova in [20].

Y. Sudus explored speech tactics of discrediting strategy in the US diplomatic discourse [16], and S. Takhtarova, D. Abuzyarova, and V. Mityagina studied mitigative tactics in digital diplomatic discourse based on the speeches of Sergey Lavrov and Boris Johnson [17].

The pragmatic aspects of the diplomatic discourse, its strategies and tactics have been studied in [6].

The goal of the paper. This paper aims to complement the existing research of the diplomatic discourse with a case study of the speeches delivered at the 8726th meeting of UN Security Council on the situation in eastern Ukraine held on 18 February 2020 [19], with the specific goal to explore the correlation between certain speech markers and the political stand of the speaker, in this particular case - each member country's stance on the agenda and the extent they choose to show their position between the two parties of the conflict, Russia and Ukraine. The meeting of 18 February 2020 was chosen as a sufficiently representative sample of the ongoing discourse on the so called "Ukraine crisis" in the UN Security Council.

The research hypothesis and methodology. To reach the aim of the research, the sixteen speeches 
delivered at the UN Security Council meeting were subjected to content analysis. These speeches were made by the representatives of Belgium, China, Dominican Republic, Estonia, France, Germany, Indonesia, Niger, Russian Federation, Saint Vincent and the Grenadines, South Africa, Tunisia, United Kingdom, United States, Vietnam and Ukraine. The purpose of the content analysis was to find in the texts of the speeches the markers which deviate from the matter-of-fact, neutral tone, expected from diplomats' speeches and could indicate the country's stance between the two conflict parties, Russia and Ukraine.

By default, all the speeches, to a greater or lesser degree, are supposed to be emotionally neutral, as required by the place and the occasion where and when they are spoken and the status of the people who pronounce them. These speeches are written beforehand and in a well-thought-out manner that shows each country's position best. In terms of their message, they all, except the speech of the Russian representative, are expected to conform to and defend the international law, i.e. to denounce aggression, express support for the independence, sovereignty and territorial integrity of Ukraine and commitment to peaceful resolution of the conflict.
Our hypothesis was that deviations from the required neutral, matter-of-fact tone and any cases of language explicitness could be taken for markers of the country's more pro-Ukrainian and less pro-Russian stance, as no country (except Russia itself) can be expected to take Russia's side in the conflict. And on the contrary, we hypothesize that the more emotionally neutral, the less evaluative and explicit the speech was, the less the speaker wanted to "tease" Russia.

The analysis of the speeches revealed the following markers, which, in our opinion, show the country's position: emotional, evaluative language and labelling, accusatory rhetoric, tools of stylistic emphasis (metaphors, expressive epithets, hyperboles, repetitions, questions, etc.), irony, ridicule, use of modals to exert pressure, idioms, etc. A specific marker that, in our opinion, clearly identifies the country's stance is identification of the conflict parties. Explicit use of geographical and other proper names contradicts the strategy of "not taking sides", which is characteristic of diplomatic summits.

To place the speeches (and the countries correspondingly) along noncommittal - explicitly pro-Ukrainian axis, we resorted to the statistical analysis of the data and calculated the percentage of the text

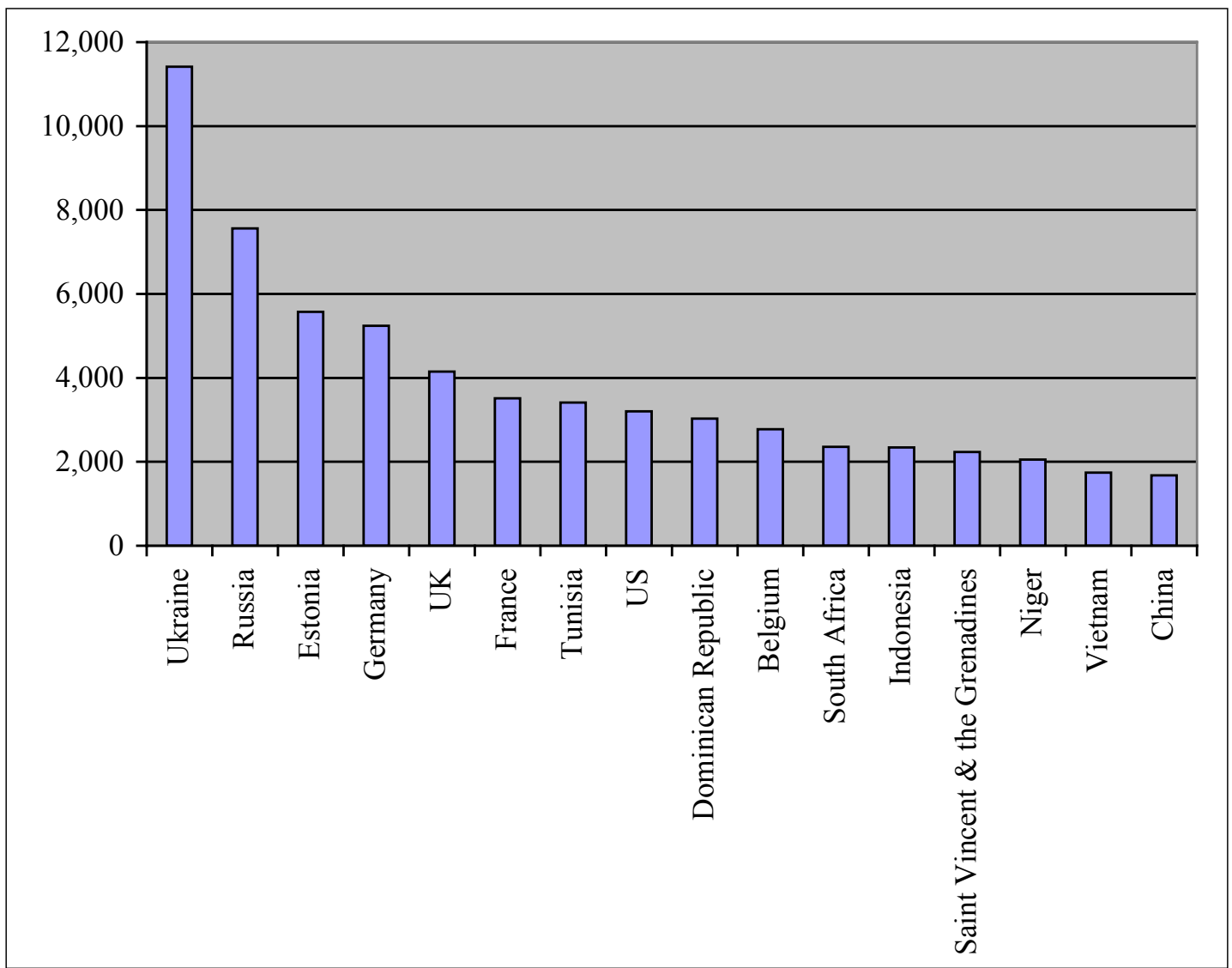

Graph 1. Length of the speeches (number of characters without spaces) 
in each speech which is free of the above-mentioned markers and can be termed "matter-of-fact".

We also looked at the length of each speech as an independent statistical value, which we believe to be an auxiliary marker of the country's stance in itself.

\section{Results and discussion}

\section{Speech length}

Graph 1 shows the length of each of the analyzed speeches calculated in the number of characters without spaces.

There are obviously no grounds to expect a direct correlation between the length of a speech and the speaker's political stance in a discussion, nevertheless, on an occasion like a UN Security Council meeting there is every reason to believe that the length of the speech will tend, at least to some extent, to be conditioned by the speaker's willingness or unwillingness to take sides with either of the conflicting parties (in this case, Russia and Ukraine) and the degree they can allow themselves to sound critical of the aggressor. Thus, we can expect that the countries which do not want or cannot afford to annoy Russia, and those which prefer to distance themselves from the agenda of Russian-Ukrainian conflict, might want to be brief and voice their opinion in general, non-committal terms.
Bearing this in mind, we can say that Graph 1 confirms, with some exceptions, our expectations. Ukraine and Russia, as the major parties involved, naturally, had the most to say, they are followed by EU countries and the United States (Tunisia's representative's speech standing out of the trend), and the shortest speech was delivered by the representative of China.

\section{Percentage of matter-of-fact language}

Graph 2 shows the share of the text in each speech devoid of the markers of emotionality, evaluativeness and explicitness.

Graph 2 shows that Russia's representative's speech was the least "diplomatic" and the most heavily laden with markers breaking with emotional neutrality and impartiality, whereas China's representative's speech was not only the shortest of all but also $100 \%$ "matter-of-fact", i.e. absolutely devoid of any emotion or evaluative stance.

The major markers found in the Russian diplomat's speech are: 1) emotional language, expressing reproach (Unfortunately, few remember that), regret (We deeply regret the fact ...), hypocritical exaggeration (for millions of residents in eastern Ukraine ... the Minsk agreements are ... the sole real hope for peace), ridicule (They have attempted to conceal their

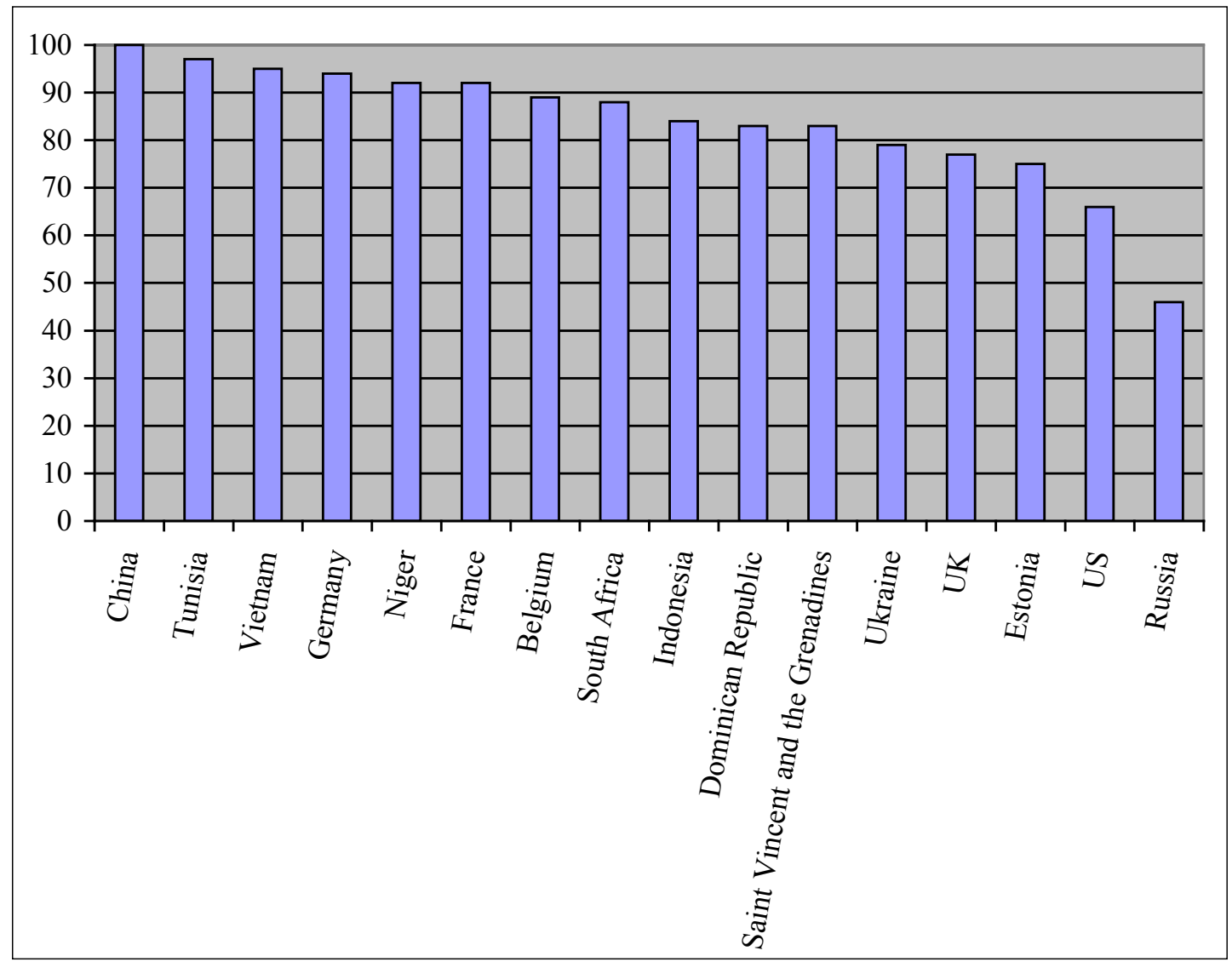

Graph 2. Percentage of matter-of-fact language (\%) 
forgetfulness by resorting to the mantra, so to speak, that the Russian Federation is failing to comply with its obligations), building up tension (What is even more alarming ...), appealing to compassion (Donbas, which former civilian militias have been protecting for all these years, risking their lives every day), containing provocative questions and other types of emphatic syntax (Are they shooting themselves? Were they the ones who started the war and marched on Kyiv?); 2) evaluative language and labelling (the anti-constitutional Maidan coup d'état, with its rabid Russophobia and nationalism); 3) metaphors (to rebuild the eroded trust of the people of Donbas); 4) use of modals to exert pressure (That position must be respected); 5) accusatory rhetoric (there is no willingness to agree on the disengagement of forces in new areas, and no readiness for direct dialogue); 6) moralizing (Will alone indeed is insufficient, what is necessary are concrete measures); 7) false claims (waging war against its own population); 8) coercion (We therefore wish to warn Council members in advance ...); 9) condescension (our Western partners ... did not deign to absorb the fact ...); 10) melodramatic embellishment (whom the residents of Donbas ... consider to be their protectors, who uphold their right to life and their identity). Such range of counter-matter-of-fact markers is found in no other speech at the meeting.

Closest to the Russian diplomat's speech in the variety (not in the number) of the markers is the speech of Ukraine's representative. Mr. Kyslytsya, in addition to emotional, evaluative, ironical and accusatory language and various figures of speech went as far as to recite Yevgeny Yevtushenko's poetry.

As we can see from Graph 2, other three speakers whose speeches show less than $80 \%$ of "matter-of-factness" are representatives of the United States (66\%), the United Kingdom (77\%) and Estonia $(75 \%)$, which agrees with their clear-cut pro-Ukrainian stance on the agenda. These speakers can afford to be explicit in their assessment of the situation. Thus, among other markers, the representative of the UK resorted to clearly formulated evaluation of the Russian speaker's account, using metaphorical language (a falsehood wrapped in a fiction inside a fairy tale), irony (uninspected "humanitarian convoys"; The Russian Ambassador spoke at length about the failure of others in fulfilling their obligations under the Minsk agreements) and straightforward accusatory rhetoric (Russia's only objective in Ukraine is to undermine that country's sovereignty and territorial integrity). The same explicitness in the evaluation of Russia's actions is seen in the speech of the US representative- bold use of evaluative metaphorical language (Russia ... fuelled the conflict in eastern Ukraine; Russia stalls and disseminates disinformation; unjustifiable role in fomenting this conflict), emotive vocabulary (alarming humanitarian crisis; an affront to international norms; we condemn; campaign of intimidation; repressive occupation), use of modals to exert pressure (Russia must end this conflict; our sanctions will remain in place; we will never accept anything less than ...). The representative of Estonia did not restrain himself in using straightforward language either (It is a grave violation of the Minsk agreements and an unfortunate display of Russia's disregard for its recommitment to the ceasefire; clearly violates the fundamental principles of international law; Russia's actions in Ukraine pose numerous threats to international peace and security; the ongoing Russian aggression against Ukraine; we condemn the illegal annexation of the Autonomous Republic of Crimea).

\section{Identification of conflict parties}

Naming parties to the conflict, using toponyms and personal names, the diplomats obviously want to be specific in their assessment of the situation and, so to say, call a spade a spade.

On the other hand, avoiding identification of conflict parties allows diplomats to maintain political ambiguity, say "the right" things without "uncomfortable" references and keep the flow of general evasive rhetoric about the necessity "to stay committed to achieving a political settlement", "seek a comprehensive solution to the crisis through dialogue and consultation", "facilitate the realization of peace, stability and development in Ukraine, promote harmony among all ethnic groups in Ukraine and foster Ukraine's peaceful coexistence with the other countries of the region", etc. (these phrases are taken from the speech of China's representative). In this regard, mentioning geographical and other proper names referring to the conflict parties seems to be a relevant marker of the speaker's stance regarding the discussed issue.

In our analysis, we counted how many times each speaker mentioned the following proper names identifying the conflict parties: Ukraine, Ukrainian, Kyiv, Donetsk, Luhansk, Donbas, Donetsk People's Republic, Luhansk People's Republic, Zelenskyy, Russia, Russian Federation, Russian, Kremlin, Moscow, Putin. The results are given in Table 1.

The speakers representing the countries in the bottom part of the table (from China down) mentioned only one party to the conflict, Ukraine, or referred to the scene of the conflict, mentioning Donbas, Donetsk and Luhansk, with the exception of the representative of South Africa, who in the first sentence of her 
Table 1

Number of mentions of proper names identifying the conflict parties

\begin{tabular}{|l|c|}
\hline \multicolumn{1}{|c|}{ Country } & Number of mentions \\
\hline Ukraine & 108 \\
\hline Russia & 52 \\
\hline Estonia & 51 \\
\hline UK & 40 \\
\hline US & 39 \\
\hline Germany & 39 \\
\hline France & 12 \\
\hline Belgium & 12 \\
\hline China & 9 \\
\hline Tunisia & 6 \\
\hline South Africa & 5 \\
\hline Vietnam & 5 \\
\hline Dominican Republic & 4 \\
\hline Indonesia & 4 \\
\hline Niger & 4 \\
\hline Saint Vincent and the Grenadines & 3 \\
\hline
\end{tabular}

speech mentioned the Russian Federation as initiator of the meeting. The only speakers (besides Ukraine's representative) who allowed themselves to mention Russia as a party to the conflict were those from Belgium, Germany, the United States, the United Kingdom and Estonia.

Interestingly, France mentions Russia only two times, in the phrases Russian-Ukrainian border and we call on ... Russia to use its influence on the separatists, thus, in fact, avoiding identification of Russia as a party to the conflict.

Conclusion and prospects of further research. The content analysis of the speeches delivered at the 8726th meeting of UN Security Council on the situation in eastern Ukraine held on 18 February 2020 made it possible to draw the following conclusions.

As a genre of diplomatic discourse, speeches delivered by diplomats at high-level meetings such as those of UN Security Council are expected to be carefully balanced in terms of the language and restrained in terms of emotions. Absence of "surprises" is ensured by the speeches being composed beforehand, which guarantees that all nuances of the delivered message are well thought of and adequately expressed in verbal form in advance.

Bearing this specificity of diplomatic speeches in mind, we conclude that any cases of deliberate emotionality, explicit evaluation of other participants' actions and deviation from diplomatic impartiality and ambiguity cannot be considered accidental and are meant to signal the speaker's distinctive position on the agenda.
The analysis of the speeches delivered at the 8726th meeting of UN Security Council on the situation in eastern Ukraine resulted in singling out language markers that break with the traditional matter-offact tone of diplomats' speeches on such occasions, the major of them being the use of emotive vocabulary and emphatic syntax, metaphors, hyperboles, idioms, evaluative language, labelling, accusatory rhetoric, modal verbs denoting obligation and determination.

Our hypothesis that the more frequent is the use of these markers in a speech, the more clearly the speaker wants to show the position of his/her country regarding the parties of the Russian-Ukrainian conflict, has been fully confirmed. The speeches with the highest number of the markers (besides those of Russia's and Ukraine's representatives) were delivered by the representatives of the United States, the United Kingdom and Estonia, the countries who openly and consistently refer to Russia's actions in Ukraine as aggression and war. The speeches of two major EU actors, Germany and France, are more emotionally restrained and differ in terms of the message. Germany's representative clearly states that "Russia took advantage of the situation. It invaded Ukraine and occupied and annexed a part of it. Among other things, a Russian Buk anti-aircraft missile was responsible for the downing of Malaysian Airlines Flight MH-17 and the death of 283 civilians". In contrast, the representative of France avoids mentioning the role of Russia in the conflict and only mentions Russia in the appeal "to use its influence on the separatists for the full implementation of the Minsk agreements".

The speech of China's representative, which is $100 \%$ devoid of any counter-matter-of-fact markers can serve as a perfect example of "on-the-fence" diplomacy and serves a good specimen of a diplomatic speech which, with appropriate adjustments, can be read and re-read on any occasion discussing an international conflict.

In our analysis, we also looked at two auxiliary markers, the number of mentions of proper names identifying the parties to the conflict and the length of speeches. The first of them showed that the participants' desire to oppose and annoy Russia is directly proportional to the number of Russia's mentions in their speeches. The length of speeches also in most cases turned out to be indicative of the speaker's intention to clearly show their position between the conflicting parties. Characteristically, China's representative's speech appeared to be not only devoid of any counter-matter-of-fact markers, i.e. the most generally and neutrally phrased, but also the briefest. 
The prospects of further research are seen in the application of the methodology of diplomatic speech analysis shown in this paper to a larger volume of texts representing diplomatic discourse, and discovering other approaches to analyzing various genres of diplomatic discourse.

\section{References:}

1. Беляков М.В. Семантико-семиотические аспекты дипломатического дискурса. Вестник Российского университета дружбы народов. Серия: Теория языка. Семиотика. Семантика. 2011. № 1. С. 59-66.

2. Кащишин Н.С. До проблеми виокремлення дипломатичного дискурсу. http://seanewdim.com/ uploads/3/4/5/1/34511564/kashchyshyn_n._problem_of_differentiation_of_the_diplomatic_discourse.pdf.

3. Кащишин Н.Є. Особливості дискурсу та терміносистеми англомовних дипломатичних документів. Наукові записки Кіровоградського державного педагогічного університету імені Володимира Винниченка. Сер. : Філологічні науки. 2009. Вип. 81(2). С. 312-316.

4. Кащишин Н.Є. Стиль текстів дипломатичних документів як поєднання стилів. Наукові записки Наиіонального університету «Острозька академія». Серія «Філологічна». Випуск 44. 2014. С. 120-123.

5. Куньч 3., Куньч М. Особливості дипломатичного мовлення як різновиду офіційно-ділового стилю. Українська наиіональна ідея: реалії та перспективи розвитку. Випуск 26, 2014. С. 121-127.

6. Седина И. В., Тоцкая Е. И. Особенности дипломатического дискурса. Дневник науки. 2017. № 5 (5). http://dnevniknauki.ru/images/publications/2017/ 5/philology/Sedina_Totskaya.pdf.

7. Скрябіна В.Б. Лінгвістичні аспекти персуазивності в дипломатичному дискурсі. Міжнародні відносини: теоретико-практичні аспекти. 2018. № 2. С. 265-274.

8. Arakelyan, Rouzanna, Avetyan, Astghik. The General and the Specific in Political and Diplomatic Discourses. Foreign Languages in Higher Education. 2017. No 1. P. 3-10.

9. Arifon, Olivier. Diplomatic Language and Formal Language: A Code with a Double Meaning. Hermès, La Revue. Vol. 58, no. 3. 2010. P. 69-78.

10. Beard, Adrian. The Language of Politics. London : Routledge, 2001. 132 p.

11. Burhanudeen, Hafriza. Diplomatic Language: An Insight from Speeches Used in International Diplomacy. Akademika. Vol. 67. No. 1.2006. P. 37-51.

12. D'Acquisto, Germana. A Linguistic Analysis of Diplomatic Discourse: UN Resolutions on the Question of Palestine. Newcastle upon Tyne : Cambridge Scholars Publishing, 2017. 140 p.

13. Marks, Sally and Freeman, Chas. W. Diplomacy. Encyclopedia Britannica. https://www.britannica.com/ topic/diplomacy.

14. Prodayvoda, Katherine. Language of Diplomacy as Language of Profession (Язык дипломатии как язык профессии) (April 23, 2021). https://ssrn.com/abstract=3852919.

15. Stanko, Nick. Use of Language in Diplomacy. Language and Diplomacy. Ed. by Jovan Kurbalija and Hannah Slavik. Malta : DiploProjects, Mediterranean Academy of Diplomatic Studies, 2001. P. 39-47.

16. Sudus, Y. Speech Tactics of Discrediting Strategy in the U.S. Diplomatic Discourse. East European Journal of Psycholinguistics. 2018. No 5(1). P. 70-82. https://doi.org/10.29038/eejpl.2018.5.1.sud.

17. Takhtarova S. S., Abuzyarova D. L., Mityagina V. A.. Mitigative Tactics in Digital Diplomatic Discourse (Based on the Speeches of S. Lavrov and B. Johnson). Proceedings of the III International Scientific and Practical Conference (DEFIN '20). March 2020. Article 9. P. 1-3. https://doi.org/10.1145/3388984.3389066.

18. Topală, Raluca-Maria. Morp hological Characteristics of the Diplomatic Language. Cultural Intertexts. Year 1. Vol. 1-2. 2014. P. 308-319.

19. United Nations Security Council. 8726th meeting. Tuesday, 18 February 2020. https://www. securitycouncilreport.org/atf/cf/\%7B65BFCF9B-6D27-4E9C-8CD3-CF6E4FF96FF9\%7D/S PV.8726.pdf.

20. Yapparova, V. Linguistic Features of Russian Diplomatic Discourse. 4th International Multidisciplinary Scientific Conference on Social Sciences and Arts SGEM 2017. Book 3, Vol 2. P. 791-796. DOI: 10.5593/ sgemsocial2017/32/S14.102.

\section{СидореНКо С. І. ДИПЛОМАТИЧНА МОВА ЯК ВІДОБРАЖЕННЯ ПОЛІТИЧНОЇ ПОЗИЦІЇ ЩОДО КОНФЛІКТУ НА СХОДІ УКРАЇНИ}

У статті наведені результати контент-аналізу дипломатичних промов на 8726-му засіданні Ради Безпеки ООН щзодо ситуаиії на сході України, яке відбулося 18 лютого 2020 року, з конкретною метою дослідити зв'язок між певними мовними ознаками та політичною позицією спікерів щодо сторін російсько-украйнського конфлікту. Як жсанр дипломатичного дискурсу, промови на засіданнях Ради Безпеки ООН очікувано мають бути ретельно виважені з погляду мовної форми та стримані з точки зору емоцій. Отже, будь-які випадки навмисної емоційності, явної оцінки дій інших учасників та відхилення від дипломатичної нейтральності мають на меті сигналізувати про бажання спікера 
недвозначно висловити свою позицію щуодо порядку денного, стати на бік однієї з сторін конфлікту. Результатом аналізу стало виділення мовних маркерів, які виходять за межі традиційної тональності промов дипломатів утаких випадках, основними яких євикористання емотивноїлексики, емфатичного синтаксису, метафор, гіпербол, ідіом, оиінної мови, «навішування ярликів», звинувачувальна риторика, модальні дієслова з семантикою обов 'язковості та наміру. Гіпотеза про те, щзо чим вище частотність таких маркерів у промові, тим ясніше спікер бажає показати позицію своєї країни щодо сторін конфлікту, повністю підтвердилася. Під час аналізу промов було розглянуто також два допоміжні маркери - кількість власних імен, що ідентифікують сторони конфлікту, та довжину промов. Перший з них показав, що бажання спікерів «дратувати» Росію прямо пропориійне кількості згадок Росії у їхніх виступах. Довжина промови також у більшості випадків свідчила про намір спікера чітко окреслити свою позицію. Характерно, що виступ представника Китаю виявився не лише позбавленим будь-яких маркерів, тобто найбільш загальним і нейтральним за мовною формою, але й найкоротшим.

Ключові слова: дипломатична мова, дипломатична промова, мовна нейтральність, маркери емоційності та оцінності, політична позиція, конфлікт на сході України. 